\title{
Another fine mess
}

\author{
Stephen Hancocks OBE \\ Editor-in-Chief
}

Send your comments to the

Editor-in-Chief,

British Dental Journal

64 Wimpole Street,

London

W1G 8YS

Email bdj@bda.org
Certain expressions have an uncanny knack of describing not only the matter in hand but also being able to match the sentiment behind the headlines. 'Flip-flop' is one that comes to mind just now, not so much as the noun to describe a style of casual footwear but as a verb to encapsulate the inability to be decisive. As the great dame of democracy that is America hoists up her skirts in readiness for the dash to the Presidential elections later this year, a process that we observe in the UK on a four-yearly cycle of distanced disbelief, like watching the ghastly inevitability of a recurring car crash in slow motion, the less than flattering term has once again been dusted down and embedded into needy Republican and Democrat sound bites.

Sadly, it might also be pressed into service on this side of the Atlantic, and at almost the same periodicity to describe the opening and closing of dental schools. Flip, one opens in response to a political imperative to fill the gap in the dentist workforce; flop, another closes as the economics dictate that we now have an oversupply. Having seen my own dental school (how extraordinarily possessive we are about these institutions), UCH, closed in the mid-1990s I have to admit to a certain chagrin at witnessing several more popping up in the mid-2000s as documented by gleeful press snaps of hard-hatted deans on bulldozers, eager dental professionals of tomorrow tree-planting and conveyer-belts of dignitaries 'topping out' facilities, pulling twee ceremonial curtains and snipping taughtly held ribbons. Surely I was not alone then in asking what would happen in about five years time? Well, welcome to the future as we now read not only in the dental press but also in the national dailies about a shortfall, real or imagined, in vocational training places for new graduates.

\section{HYGIENISTS 'SET ASIDE'}

From tracking the debate on web-fora and various other anecdotal conversations in recent months, I suspect we are entering or have already embarked upon a period of 'he said, she said' in terms of how many places have been placed, the quantity of the displaced that have been displaced and the number of disaffected who are now disaffected. But what is emerging is another fine mess along the lines of the lingering destiny of our inability to get the dental workforce in balance. History is littered with examples from the Teviot Report in 1945 through to the Nuffields of the 1990s interspersed with the erudite documentation of innumerable other Working Parties, Study Groups and Planning Committees in the intervening years which have served only to bounce dental education up into the air or judder it down to the ground on the see-saw of uncertainty.

It would be lovely to have someone to blame. As a society, fuelled by the need of the media to persecute a scapegoat, we like nothing better than to drag a reputation through the mud. The truth of the matter though is that no one person or body is responsible, perhaps the solution to the matter as well as the cause. The Department (or successive Departments), the BDA, the GDC, the universities, various governments; at none of these doors can the blame be neatly stacked and a bonfire lit. The complexities of workforce supply, especially in an economic union such as the European Community as well as the confustications of third party payment systems such as the NHS, clash head-on with a demand which is almost without definition, virtually unmeasurable and infinitely subject to disease patterns, patient whims and aesthetic fashion. Stalemate.

Except that as a profession we are left not only with numbers but with real people, colleagues, who are unable to practise that for which they have spent five or more years training. The consequences are given even greater drama by being dropped into the maelstrom of an economic downturn. So, not only are graduates out of work but hygienists are being 'set aside' by dentists now anxious to maximise their own surgery time and save on the wage bill. If it all sounds reminiscent of the flip-flopping that dental therapists have experienced over the years of, oh yes, opening and closing dental therapy schools and courses then it is probably no coincidence.

The uncomfortable truth is that no one single entity is able to do much about it, apart from the market and that, as we know from our experience of buying carrots to selling homes, is not always a comfortable place to be. It never has a cosy place for sentiment however much we may blather about rights to work, years of study or society's investment in the future. I fear that as we while away the hours waiting for the good times to return we will also need to engage in greater creativity. Diversity is about more than recognising human differences, surviving has as much to do with lateral thinking as it does with creating opportunities and prospering requires not only celebrating success but also managing hardship. It would seem fair and fluffy and lovely to be able to find a villain, wave a wand and make everything well again but the new world is quite different. Flip if you can, flop if you can't.

DOI: 10.1038/sj.bdj.2012.3 